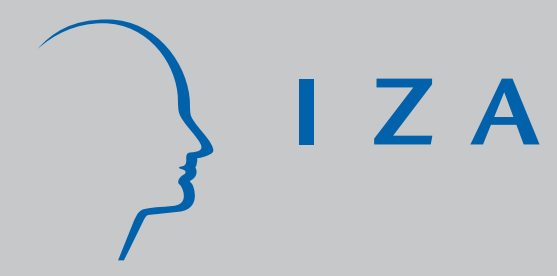

IZA DP No. 7688

Is Climbing Difficult? A Gendered Analysis on the Use of Financial Services in Ghana and South Africa

Samuel Annim

Thankom Arun

October 2013 


\title{
Is Climbing Difficult? A Gendered Analysis on the Use of Financial Services in Ghana and South Africa
}

\author{
Samuel Annim \\ University of Central Lancashire \\ Thankom Arun \\ University of Central Lancashire \\ and IZA
}

Discussion Paper No. 7688

October 2013

IZA

P.O. Box 7240

53072 Bonn

Germany

\author{
Phone: +49-228-3894-0 \\ Fax: +49-228-3894-180 \\ E-mail: iza@iza.org
}

\begin{abstract}
Any opinions expressed here are those of the author(s) and not those of IZA. Research published in this series may include views on policy, but the institute itself takes no institutional policy positions. The IZA research network is committed to the IZA Guiding Principles of Research Integrity.

The Institute for the Study of Labor (IZA) in Bonn is a local and virtual international research center and a place of communication between science, politics and business. IZA is an independent nonprofit organization supported by Deutsche Post Foundation. The center is associated with the University of Bonn and offers a stimulating research environment through its international network, workshops and conferences, data service, project support, research visits and doctoral program. IZA engages in (i) original and internationally competitive research in all fields of labor economics, (ii) development of policy concepts, and (iii) dissemination of research results and concepts to the interested public.
\end{abstract}

IZA Discussion Papers often represent preliminary work and are circulated to encourage discussion. Citation of such a paper should account for its provisional character. A revised version may be available directly from the author. 
IZA Discussion Paper No. 7688

October 2013

\section{ABSTRACT}

\section{Is Climbing Difficult? A Gendered Analysis on the Use of Financial Services in Ghana and South Africa}

This paper examines the gender gaps in the use of higher-order financial services such as investment and insurance, draws on the FinMark national-level data from Ghana and South Africa. The main observation is that females in South Africa are more likely to use general financial and investment products than in Ghana. The results also reveal that in Ghana, a substantial part of the gender differentials in the use of financial services can be attributed to unobserved characteristics, mostly related to attitude and perceptions that inhibit women's use of financial services.

JEL Classification: G21, J16

Keywords: $\quad$ gender gaps, types and levels of access to finance, Ghana and South Africa

Corresponding author:

Thankom Arun

Institute of Global Finance and Development

Lancashire Business School, University of Central Lancashire

Preston, PR1 2HE

United Kingdom

E-mail: tgarun@uclan.ac.uk 


\section{Introduction}

Although better provision of access to financial resources available to women is believed to promote entrepreneurship and enhance women's participation in economic activity, most of the debates assume access is homogeneous rather than focusing on types and levels of financial service. Access to financial services can improve ownership and serve as a catalyst to greater economic empowerment among women, and further engender the achievement of Millennium Development Goals (MDG) 2 and 7 (Napier et al., 2013). Demirgüç-Kunt et al. (2013) argue that even a basic financial tool such as a deposit account can help significantly by creating a reliable payment connection between family members, employer and government. Nevertheless, in reality, female-managed firms are less likely to obtain a bank loan in many countries, and the probability of receiving a loan is about 5 per cent lower for female-owned/managed firms than for male-owned/managed enterprises (Muravyev et al., 2009). Based on the Business Environment and Enterprise Performance Survey (BEEPS) across 34 countries (mostly in Europe and Asia), Muravyev et al. (2009) noticed that the gender-based discrimination is lower in countries with more developed financial markets, a view supported by Becker-type discrimination. There is an absolute difference in terms of the use of financial services between the developed and developing countries. According to a UN Survey, 89 per cent of the population of the EU have access to a bank account whereas in developing countries, this ranges from 6 to 47 per cent (Narain, 2009). As expected, in high income countries 87.4 per cent of women have an account with a formal financial institution, whereas the figure is 21.5 per cent in sub-Saharan Africa (GFI, 2011). In terms of using the accounts for business purposes, the figures for high-income countries and sub-Saharan Africa are 22.1 per cent and 4 per cent respectively. However, Aterido et al. (2011) found no evidence of a gender gap in access and use of financial services by women entrepreneurs in sub-Saharan Africa. Given these varied empirical findings, this paper contributes to the ongoing debate by examining the types and levels of access and use of financial services, and the sources of gender differentials in two vibrant economies in sub-Saharan Africa: Ghana and South Africa.

\section{Background}

The discussion on the universal use of financial services and products has been intense, mostly on the issues of provision and use of financial services. The supply-side issues have 
mainly emphasised the aspects of accessibility that are making financial products both available and affordable, and on designing products in a reliable and flexible manner (Claessens, 2006). The discourse has been extended to the regulatory framework for protecting consumers and making sure that new financial markets integrate well into the industry (Annim et al., 2012). One would expect these attempts to reduce the incidence of financial exclusion; however, the prevalence of financial exclusion remains high in developing countries.

Intermittent downturns in access and use of financial services have been observed in South Africa, irrespective of the fact that the country enjoys better access to finance than other countries in the region. For instance, the FinMark Trust (2009) reports a 3 per cent drop in the proportion of South Africans using a bank service. These findings indicate the need for more evidence on the demand side, which has led to a recent increase in the number of studies that have concentrated on the demand-side factors of access to financial markets (Annim et al., 2012; Baue et al, 2012; Kostov et al., 2011; Narain, 2009). Narain (2009) outlines inadequate information about bank products and services, long and frustrating application processes, perception that banks do not grant loans to low-income people, lack of collateral, and lack of repayment capacity because of insufficient secured income, as some of the leading demand-side issues that adversely affect financial inclusion. The literature has also explored how issues such as perception, behaviour and attitudes contribute to financial access and inclusion (Annim et al., 2012).

While both men and women may be faced with the constraints outlined above, by reasons of culture, institutional structures and traditional rational collateral, females are perceived to have stiffer barriers than males, and the effects of exclusion vary across gender. The cultural and traditional factors that result in gender discrimination in the access and use of financial services are mostly intangible and innate, and therefore unobservable for measurement. However, from a policy perspective, it would be of interest to know if these gender differences in access and the use of financial services can be explained mainly by differences in socio-economic characteristics, or whether they are mainly due to behavioural characteristics associated with males and females. In line with this broad policy objective, this paper specifically seeks to examine the effect of gender on access and use of (i) general accounts and services, (ii) investment accounts, and (iii) insurance and life assurance services. As indicated, it is also the objective of this paper to decompose the gender 
difference to identify how much of it is a result of differences in behaviour. Based on these objectives we test the following hypotheses: (1) there is no gender difference in access and use of financial services; (2) gender differences, if any, are not explained by unobservable characteristics, and (3) patterns of gender differentials, if any, vary between Ghana and South Africa for the three types of financial service.

Since 1987, Ghana has implemented reforms in the financial sector; interest rate caps and allocation of credit to priority sectors were abolished as part of the reform. Recent legislation on venture capital (2004), insolvency (2006) and credit reporting (2006) shows the desire to create an enabling atmosphere in Ghana. Further, changes in the regulatory framework ensure significant improvements in the legal basis for financial intermediation, particularly on prudential supervision, capital adequacy, bank risk management, and more onsite supervision. During this period, the financial environment in South Africa has also witnessed substantial changes in financial regulations and innovations, and partnerships across all financial institutions (Annim et al., 2012). For instance, the Mzansi initiative was introduced in 2004 by the four major private banks in South Africa, ABSA, Nedbank, Standard and First National, to reach the "unbanked". Financial regulation in South Africa is on a single regulatory regime with a bias to adopt the "twin peak" financial regulation system to overcome differences in the skill sets needed for prudential and market conduct regulations. In recent times regulatory interventions such as the promulgation of the Consumer Protection Act (Act No. 68 of 2008) have also taken place, adjusting the industry to emerging global trends. The introduction of these many policies and regulations in both Ghana and South Africa could stifle innovation in the sector and constrain attempts to increase financial access and inclusion.

While it is apparent that in both Ghana and South Africa conscious efforts have been instituted to ensure access to financial services, it is worth noting that this does not automatically translate to use of financial services. Thus, cognizant of the emerging consensus that access to finance is mainly a supply-side issue that has to do with the supply of reasonable quality financial services at reasonable costs (Claessens, 2006), the issue of reasonability with regard to cost should be expressed holistically to encompass both monetary and non-monetary costs. Use of financial services, on the other hand, has been explained to mean the actual consumption of these services. Thus, whilst access can be viewed as a purely supply-side problem, the use of financial services has both supply and demand as its 
determinants. Access should therefore be viewed as a prerequisite to the use of financial services.

The important question that needs to be answered is what causes voluntary and involuntary exclusion in financial services. In most cases, voluntary exclusion is caused by lack of access, assumed rejection based on socio-economic characteristics, and high costs that put services out of reach of the unbanked. That is, some individuals will not have access if there are no distribution points of financial institutions in their locality. The supply curve is vertical at zero for such people. Other consumers are deterred from seeking financial services from the market because they are charged high-risk premiums as a result of lack of credit information. The last resort for this group then becomes the informal money lenders. It should also be noted that the lack of a credit history may arise from such barriers as a weak institutional environment, including poorly functioning credit information bureaus (Claessens, 2006). Finally, those who are excluded may have their own perceived economic and social barriers.

Involuntary exclusion leads to disequilibrium in the demand and supply of financial services. Whilst the notion that use will vary with access is a standard result of demand and supply, the work of Stiglitz and Weiss (1981) has shown that in the face of information asymmetries, lenders will not only adjust the price but also the quantity of credit they are willing to supply. In the view of Claessens (2006), depending on the distribution of borrowers' risk and return and other factors such as the level of income, the demand for financial services can be backward bending, leading to quantity rationing. This will lead to involuntary exclusion, although from the supply side it is a rational market response. Having to estimate the effect of adverse selection and moral hazards can make it hard to separate them empirically, and this goes further to compound the difficulty in determining whether an individual or firm has voluntarily decided not to use financial services or whether such individuals or firms are "rationed out". The extent to which one can distinguish between access and use of financial services also depends on the aspect of the service that is being considered: insurance, investment, savings mobilisation or issuing credit. In view of the different types of financial service, it is important to indicate the nature of exclusion in the event where an individual uses just a fraction of the different types of financial service. The foregoing suggests that identifying, understanding and addressing the issue of exclusion can be daunting. 
To make the issue of definition easier, some practitioners have restricted the concept of access to availability, cost, range type and quality of financial services. The dimensions of availability include: are financial services available, and if so in what quantity? Second is the question of cost: what is the monetary value of the available financial services, including the opportunity costs of having to wait in line for a teller or having to travel a long distance to a bank branch? Third is the range, type and quality of the services being offered. Following Morduch (1999), these dimensions can be identified as reliability (is financial service available when needed?); convenience (is access to financial service easy?); continuity (can financial service be accessed repeatedly?); and flexibility (is the financial product tailored to individual needs?). The third component is particularly hard to measure and so has been excluded from empirical papers. Cognizant of this complexity, in conceptualising access to and use of financial services, this paper disaggregates the concept of access into types and levels. Details of the disaggregation are provided in the next section.

The rest of this paper is organised as follows: the next section looks at the data and models of estimation and measurement of variables. The third section presents a discussion of the results of the analysis, as well as the major conclusions that are drawn from the paper; and, finally, policy recommendations.

\section{Data and Methods}

This paper uses data from the FinScope surveys rolled out in Ghana and South Africa in 2010. The roll-out of FinScope surveys is an initiative of the FinMark Trust (an independent trust funded primarily by UKaid, the United Kingdom's Department for International Development). The survey is nationally representative and conducted in a number of sub-Saharan African countries with the aim of contributing to an understanding of consumers' perceptions and behaviour in terms of their use of financial services. The survey also captures information on attitudes, quality of life and consumption patterns. In view of this mandate, the survey collects information on a broad range of issues including financial services and socio-economic characteristics. 
The sample for the FinScope survey is drawn from the adult population (above 15 and 16 years respectively in Ghana and South Africa), hence the unit of sampling is the individual. The sampling approach takes into consideration the rural-urban divide in the country as well as the concentration of informal sectors. Based on a multi-stage sampling approach, 3,648 respondents were interviewed in Ghana and 3,900 in South Africa. Generally, the survey is essentially the same with regards to the issues investigated in the two countries. However, country-specific issues were also incorporated, resulting in slight variations in the questionnaire. The content of the FinScope instrument is as follows: (i) Household register; (ii) Financial literacy; (iii) Overall financial perception; (iv) Banking penetration (transaction channels, Mzansi and credit and loans); (v) Insurance products and services (funeral cover and retirement/pension); (vi) Investment/savings; (vii) Lifestyles; (viii) Access to amenities and use of information, communication and technology (ICT); (ix) Sources of money; and (x) Personal and household's socio-economic and demographic characteristics.

The section on financial products and use were used to construct the three outcome variables (types of financial service use): (i) level of use of general accounts and services, (ii) level of use of insurance services; and (iii) level of use of investment services. Each of the financial products was first classified under one of these three headings. Then, following Annim et al. (2012), they were further classified into levels of use, namely: pre-account (none) (coded as 1); basic account (coded as 2); intermediate account (coded as 3); and advanced account (coded as 4). The detailed coding used in this paper is given in Appendix A1. Respondents were asked their gender and we recoded this variable assigning 1 to females and 0 to males. The paper also controls for other variables such as age, income level, education and household size. We also controlled for regional and province effects by introducing a set of dummy variables. To take care of racial heterogeneity in South African society we included race dummies to capture the race effect. Since racial heterogeneity is not an issue in Ghana, we ran two separate models for South Africa, which is with and without race, for the sake of comparability. The results of the model are presented as Appendix B.

The study controlled for supply-side factors that affect the decision to use financial services. Specifically, the supply-side factors considered are: working hours of financial institutions; cost of service provision (interest rate and other transactional costs); return on deposits; staff attitude; travelling distance to financial institutions; time spent in engaging in a financial service; and sense of intimidation in the banking hall. The variables were captured 
in this paper by counting the number of such constraints faced by each individual. In the case of Ghana, eight such questions were identified, with five for South Africa.

The current paper employs ordered logit models in its analysis. The choice of ordered logit is appropriate because the dependent variables are ranked from 1 to 4 in each case, with higher values representing higher levels of use of these products. We then estimate the odds ratios since the coefficients in themselves mean very little in terms of interpretation. To decompose the coefficient of sex (gender) into the relative contributions of observed and unobserved characteristics of males and females, we employ the Blinder-Oaxaca decomposition for non-linear regression models (Sinning, Hahn, \& Bauer, 2008).

Given a linear regression model for two groups $g=(A, B)$ of the form

$Y_{i g}=X_{i g} \beta_{g}+\epsilon_{i g}$

where $i=1, \ldots N_{g}$ and $\Sigma_{g} N_{g}=N$. The ordinary Blinder-Oaxaca decomposition of this model will be given as:

$\bar{Y}_{A}-\bar{Y}_{B}=\Delta^{O L S}=\left(\overline{\boldsymbol{X}}_{\boldsymbol{A}}-\overline{\boldsymbol{X}}_{\boldsymbol{B}}\right) \beta_{A}+\overline{\boldsymbol{X}}_{B}\left(\hat{\beta}_{A}-\hat{\beta}_{B}\right)$

This type of decomposition will not be appropriate in our model because the outcome variable is nonlinear because the conditional expectation of $E\left(Y_{i g} \mid X_{i g}\right)$, may differ from $\overline{\boldsymbol{X}}_{g} \bar{\beta}_{g}$ (Sinning et al., 2008). (Sinning et al., 2008) transforms the (1) to obtain a general version of the blinder Blinder-Oaxaca decomposition as:

$\Delta_{A}^{N L}=\left[E_{\beta_{A}}\left(Y_{i A} \mid \boldsymbol{X}_{i A}\right)-E_{\beta A}\left(Y_{i B} \mid \boldsymbol{X}_{i B}\right)\right]+\left[E_{\beta A}\left(Y_{i B} \mid \boldsymbol{X}_{i B}\right)-E_{\beta B}\left(Y_{i B} \mid \boldsymbol{X}_{i B}\right)\right]$

where $E_{\beta_{g}}\left(Y_{i g} \mid \boldsymbol{X}_{i g}\right)$ is the conditional expectation of $Y_{i g}$ and $E_{\beta_{g}}\left(Y_{i h} \mid \boldsymbol{X}_{i h}\right)$ represents the conditional expectation of $Y_{i h}$ evaluated at the parameter vector $\beta_{g}$. In this set up $g, h=(A, B)$ and $g \neq h$. The first term on the right hand side displays the differential in the outcome variable between A and B as a result of differences in the explanatory variables in $\boldsymbol{X}_{i g}$, and the other term shows the part differential that is due to differences of the coefficient. The ologit sample counterpart of this technique is given by:

$$
\begin{gathered}
\frac{1}{N_{g}} \Sigma_{1=1}^{N}\left[\left\{\Lambda\left(\widehat{\mu_{1}}-\boldsymbol{X}_{i g} \widehat{\beta_{g}}\right)-\Lambda\left(-\boldsymbol{X}_{i g} \widehat{\beta_{g}}\right)\right\}+2\left\{\Lambda\left(\widehat{\mu_{2}}-\boldsymbol{X}_{i g} \widehat{\beta_{g}}\right)-\Lambda\left(\widehat{\mu_{1}}-\boldsymbol{X}_{i g} \widehat{\beta_{g}}\right)\right\}\right. \\
\left.+\cdots J\left\{1-\Lambda\left(\widehat{\mu_{J-1}}-\boldsymbol{X}_{i g} \widehat{\beta_{g}}\right)\right\}\right]
\end{gathered}
$$


Where $J$ is the number of possible outcomes and $\widehat{\mu}, \ldots \mu_{J-1}$ are the estimated threshold values of the ordered logit.

\section{Results and Discussion}

The results from the econometric analysis are preceded by a descriptive overview of the use of financial services across the different types and the levels of each type. Figures 1 to 3 present the descriptive results based on gender differences for both Ghana and South Africa. Consistent with the respective FinScope reports, the proportion of females is greater than males in both Ghana and South Africa. Figure 1 shows that more than half of both men and women in Ghana either do not use a general account or service, or use a pre-account. This pattern is also observed for the use of investment products (Figure 2) and insurance services (Figure 3).

For South Africa, we observe a 1 per cent gender difference in all the levels for the general accounts and services, with the exception of the advanced level where a 3 per cent difference in favour of men is observed. In sum, for general accounts and services, larger gender differences in favour of men are observed in Ghana relative to differences in South Africa. In spite of this, the Chi-square test shows that the gender difference is statistically significant, suggesting that the difference is not by chance in either country and is therefore driven by either observed or unobserved factors.

Figure 2 shows that in South Africa, about half of both men and women do not use an investment product, while in Ghana only one out of ten people uses an investment product. Also from Figure 2, we observe a significant difference in the proportion of use of basic investment products in both Ghana and South Africa. While in South Africa about half of the adult population use some form of basic investment product, in Ghana less than 10 per cent of the adult population use a basic investment product. In a gender context, more females in both countries use basic investment products while more males in both countries use advanced investment products. Thus men are likely to have advanced investment products such as mutual fund, provident fund and ownership of treasury bills and shares and stocks. On the other hand, the use of investment products such as the collection of antiques, unit trusts, livestock and so forth is more common among women (52\%) than men (50\%) in South Africa. 
Figure 3 presents the descriptive analysis of the use of insurance services in Ghana and South Africa by gender. As with the observation on the use of investment products, Figure 3 shows that about half the adult population in South Africa use insurance services, while in Ghana only 5 per cent and 11 per cent of the female and male adult population respectively use an insurance service. In terms of gender differences, 4 per cent of females use intermediate insurance services, compared to 9 per cent of males. Though negligible, the proportion of males and females who use advanced insurance services in Ghana is the same for adult males and females, that is 1 per cent. In South Africa, more males use advanced insurance services than do their female counterparts (Figure 3). However, in terms of basic insurance services such as funeral, provident, pension and education, the proportion of females using these services is greater than that of their male counterparts. The FinMark Trust (2011) report indicates that about 21 per cent of females patronise burial and funeral insurance services, compared to 11 per cent of males. This corroborates our evidence that more females (29\%) than males (19\%) use basic insurance services.

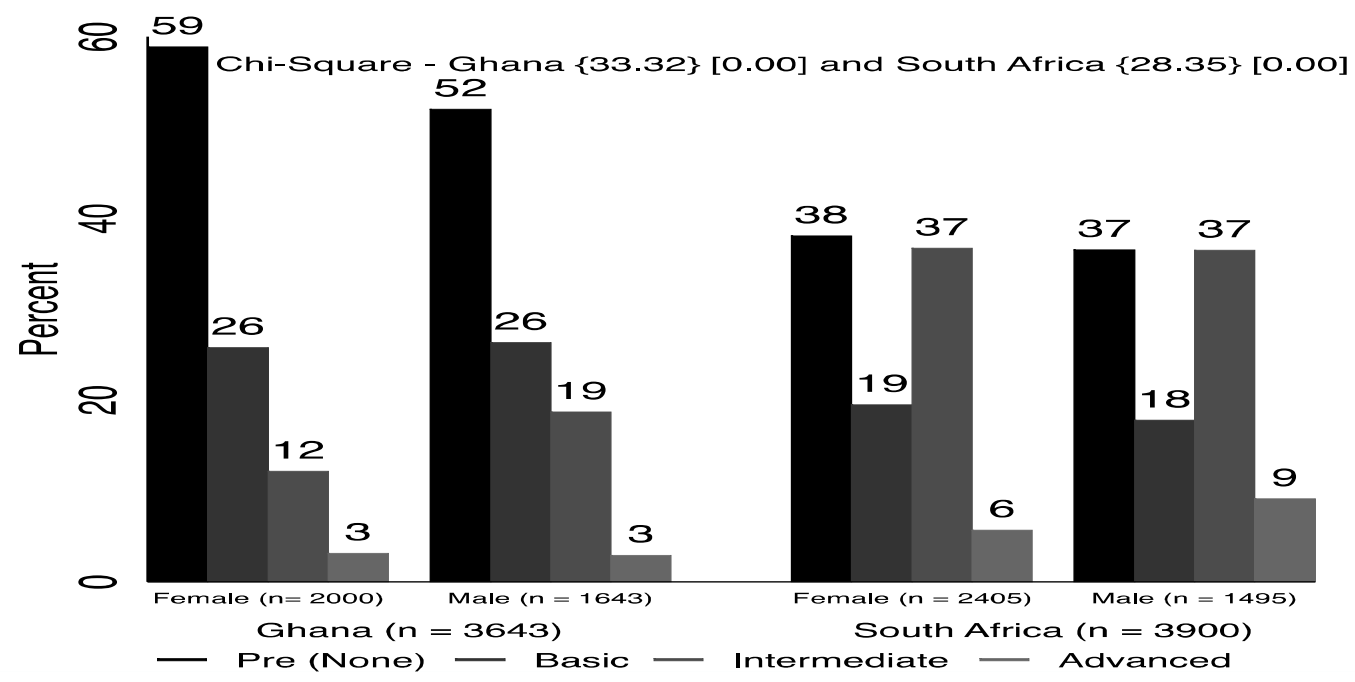

Figure 1: Levels of Use of General Accounts and Services by Sex in Ghana and South Africa in 2010 


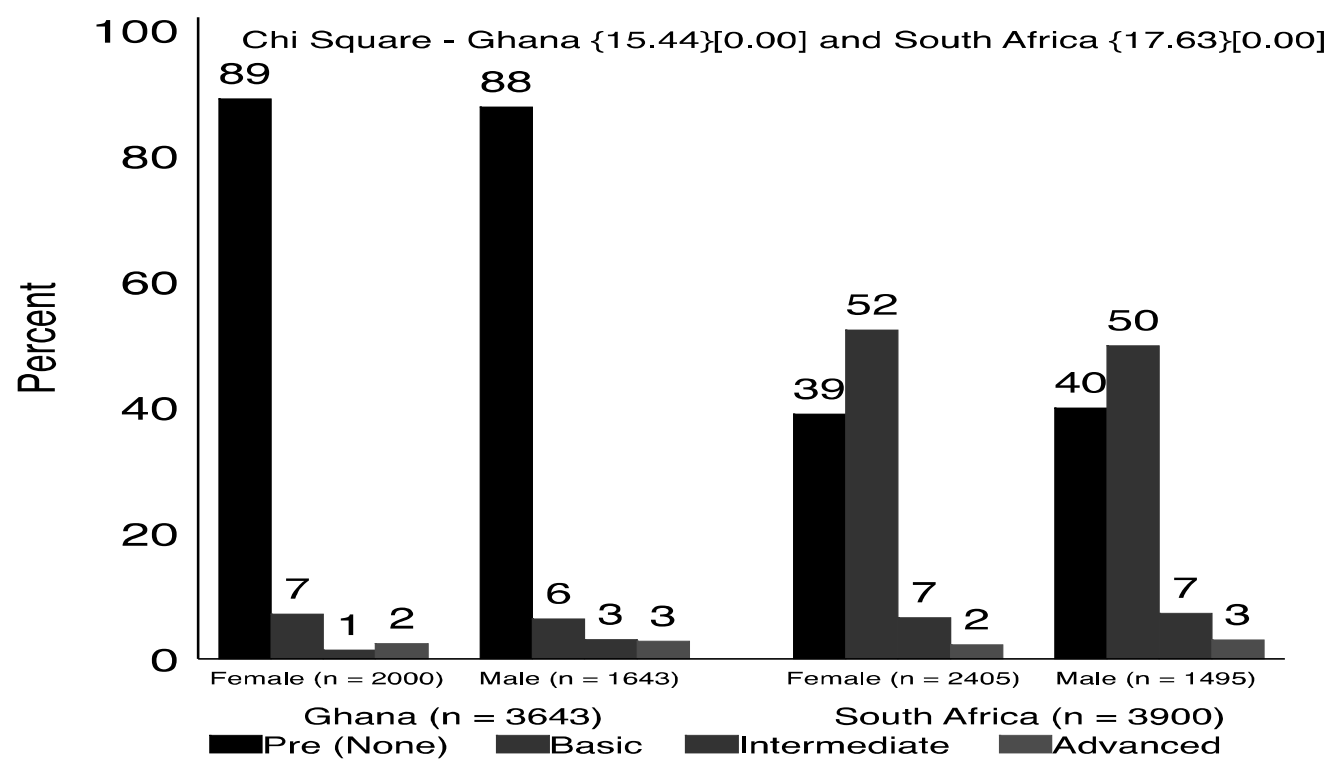

Figure 2: Levels of Use of Investment Products by Sex in Ghana and South Africa in 2010

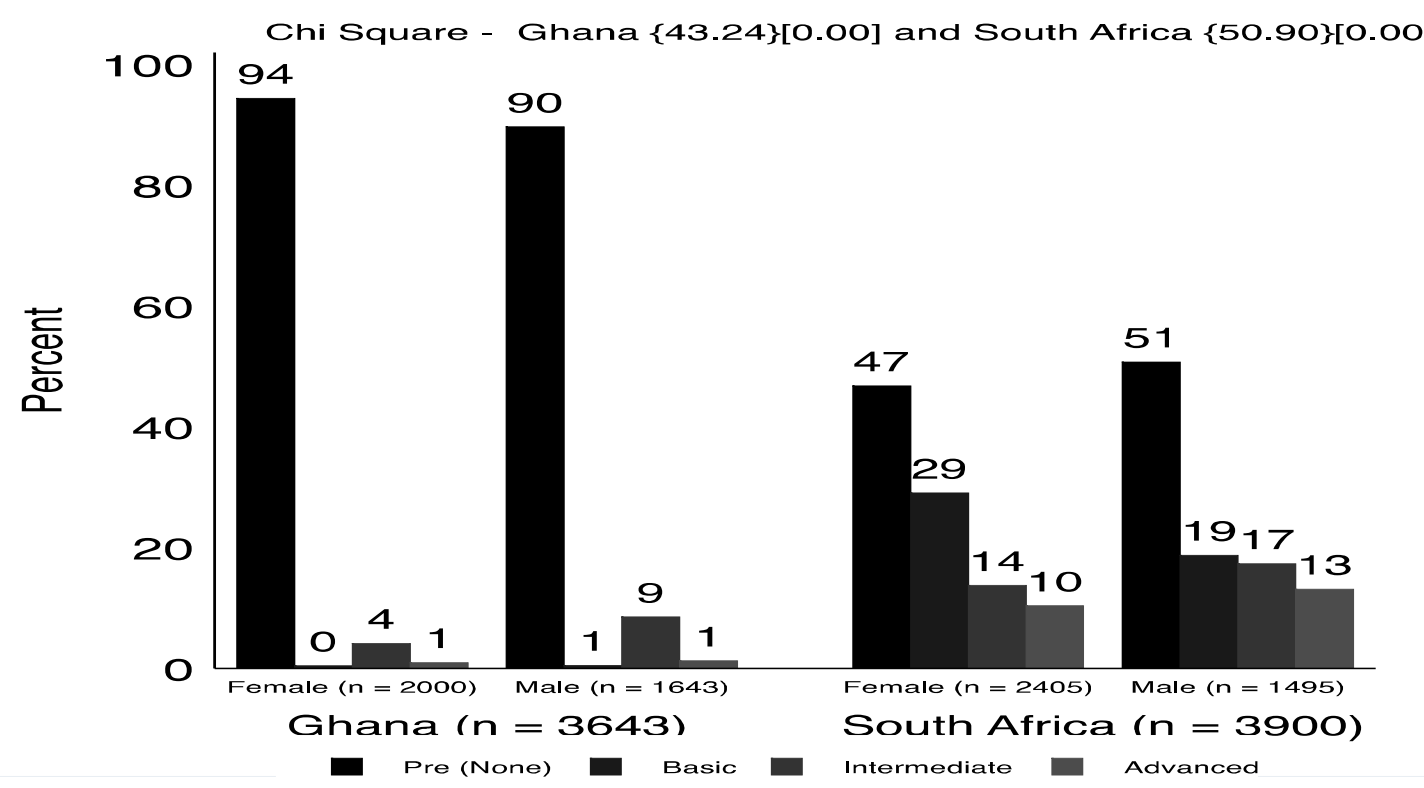

Figure 3: Levels of Use of Insurance Products by Sex in Ghana and South Africa in 2010

Tables 1 and 3 present the ordered logit results for each of the three financial services in Ghana and South Africa respectively. The summary statistics of the variables used in the ordered logit models are presented in Appendix C. The two tables show that gender significantly influences use of general accounts and services and insurance in both Ghana and South Africa. However, the estimated results fail to find evidence of differences in terms of use of investment services across gender in either country. The sign of the gender variable in Table 1 is consistent with a priori expectations. According to the results, the females are 29 
per cent less likely to use general account and services and 44 per cent less likely to use insurance services. However, central to expectations, females in South Africa are more likely to use general account and insurance services than their male counterparts. From Table 3, the odds of using general account are 26 per cent higher for females than for males, and 54 per cent higher when considering insurance services. Thus the results show that females in Ghana are financially excluded, but we fail to find the same evidence for South Africa.

We observe that age is a significant determinant of the use of all the products in Ghana. However, in the case of South Africa, age is significant only in explaining the use of insurance services. From Table 1, a unit increase in age is associated with about a 3 per cent chance that the person will use a higher level of general account and services and insurance, and about a 2 per cent chance that they will use a higher level investment service in Ghana. For South Africa, on the other hand, the odds of using insurance services increase by 3 per cent per unit increase in age. Our findings are consistent with earlier works by Annim et al. (2012) and Barslund \& Tarp (2008).

Levels of education tend to be highly significant in explaining levels of use of financial services in both Ghana and South Africa. The effect of education is confirmed in all the models except the investment model of South Africa. The signs of the set of education dummies are consistent with a priori expectations. The implication of this finding is that educated people are more likely to use higher levels of these financial services. This is because education tends to enlighten individuals on the benefits of engaging the services of a financial institution, specifically for higher-level financial products; thus, insurance, savings and investment receive their patronage.

A dummy variable (urban) was introduced to capture the rural-urban divide. In these countries, as in the case of most African countries, rural areas are inhabited by poor agrarian people whose demand for financial services may be constrained by their socio-economic conditions. These may be either supply or demand-side issues, such as low income or absence of financial institutions. However, residing in an urban area proves to increase the chance of using all the financial services and general account and investment services in South Africa. To examine the effect of being married on the use of these financial services, a married dummy was introduced in the model. In both countries, this variable is significant in some of the models. For example, in Ghana being married increases one's of chance of using an investment account by 33.4 per cent. In South Africa, on the other hand, married people have 
about a 94 per cent higher chance of using general account and services and a 90 per cent chance of using an insurance service. Intuitively, the sign of this variable is expected since married people may have greater responsibilities that cause them to save and invest for the future. 
Table 1: Ordered Logit Estimation of Usage of Various Financial Services in Ghana

\begin{tabular}{|c|c|c|c|c|c|c|}
\hline \multirow{2}{*}{ female } & \multicolumn{2}{|c|}{ (1) } & \multicolumn{2}{|c|}{$(2)$} & \multicolumn{2}{|c|}{ (3) } \\
\hline & \multicolumn{2}{|c|}{ General Account and Service } & \multicolumn{2}{|c|}{ Insurance } & \multicolumn{2}{|c|}{ Investment } \\
\hline female & $\begin{array}{l}-0.325 \text { *** } \\
(-4.16)\end{array}$ & -27.74 & $\begin{array}{l}-0.560 * * * \\
(-3.64)\end{array}$ & -42.90 & $\begin{array}{l}-0.0181 \\
(-0.15)\end{array}$ & -1.790 \\
\hline Age & $\begin{array}{l}0.0270 * * * \\
(10.27)\end{array}$ & 2.734 & $\begin{array}{l}0.0341 * * * \\
(7.10)\end{array}$ & 3.473 & $\begin{array}{l}0.0169 \text { *** } \\
(4.18)\end{array}$ & 1.705 \\
\hline HH. Size & $\begin{array}{l}0.0248 \\
(1.07)\end{array}$ & 2.510 & $\begin{array}{l}0.00113 \\
(0.03)\end{array}$ & 0.113 & $\begin{array}{l}-0.0414 \\
(-1.12)\end{array}$ & -4.054 \\
\hline Urban & $\begin{array}{l}0.782 * * * \\
(8.85)\end{array}$ & 118.7 & $\begin{array}{l}0.845^{* * * *} \\
(4.62)\end{array}$ & 132.7 & $\begin{array}{l}0.644^{* * * *} \\
(4.72)\end{array}$ & 90.50 \\
\hline No. Of reasons & $\begin{array}{l}-0.506^{* * *} \\
(-6.01)\end{array}$ & -39.70 & $\begin{array}{l}-0.259+ \\
(-1.65)\end{array}$ & -22.84 & $\begin{array}{l}-0.0897 \\
(-0.83)\end{array}$ & -8.581 \\
\hline Married & $\begin{array}{l}0.320 * * * \\
(4.02)\end{array}$ & & $\begin{array}{l}0.208 \\
(1.32)\end{array}$ & & $\begin{array}{l}0.288^{*} \\
(2.31)\end{array}$ & 33.4 \\
\hline \multicolumn{7}{|l|}{ Education } \\
\hline Basic sch. & $\begin{array}{l}0.923 * * * \\
(7.54)\end{array}$ & 151.6 & $\begin{array}{l}0.643 * \\
(2.35)\end{array}$ & 90.19 & $\begin{array}{l}0.594 * * \\
(3.04)\end{array}$ & 81.16 \\
\hline Secondary sch. & $\begin{array}{l}1.687 * * * \\
(11.61)\end{array}$ & 440.4 & $\begin{array}{l}1.369 * * * \\
(4.62)\end{array}$ & 293.0 & $\begin{array}{l}0.891 * * * \\
(3.94)\end{array}$ & 143.7 \\
\hline Post sec. & $\begin{array}{l}2.609 * * * \\
(10.98)\end{array}$ & 1258.8 & $\begin{array}{l}2.452 \text { *** } \\
(6.90)\end{array}$ & 1061.2 & $\begin{array}{l}1.531 \text { *** } \\
(4.89)\end{array}$ & 362.1 \\
\hline University & $2.959 * * *$ & 1828.7 & $2.712 * * *$ & 1406.2 & $2.583 * * *$ & 1224.1 \\
\hline Income & & & & & & \\
\hline Below 600 & $\begin{array}{l}1.016^{* * * *} \\
(8.27)\end{array}$ & 176.1 & $\begin{array}{l}1.178 * * * \\
(3.82)\end{array}$ & 224.8 & $\begin{array}{l}0.865 * * * \\
(3.95)\end{array}$ & 137.6 \\
\hline Betw. 601 and 1200 & $\begin{array}{l}1.286 * * * \\
(4.65)\end{array}$ & 261.8 & $\begin{array}{l}1.519 * * \\
(3.25)\end{array}$ & 356.8 & $\begin{array}{l}1.311 * * * \\
(3.38)\end{array}$ & 270.8 \\
\hline Betw. 1201 and 1800 & $\begin{array}{l}1.400^{*} \\
(2.53)\end{array}$ & 305.6 & $\begin{array}{l}-0.430 \\
(-0.28)\end{array}$ & -34.9 & $\begin{array}{l}0.720 \\
(0.94)\end{array}$ & 105.4 \\
\hline Over 1801 & $\begin{array}{l}1.132+ \\
(1.67)\end{array}$ & 210.2 & $\begin{array}{l}0.0902 \\
(0.09)\end{array}$ & 9.4 & $\begin{array}{l}0.727 \\
(0.76)\end{array}$ & 106.9 \\
\hline \multicolumn{7}{|l|}{ Region } \\
\hline Western & $\begin{array}{l}-0.110 \\
(-0.72)\end{array}$ & -10.45 & $\begin{array}{l}-0.681^{*} \\
(-2.26)\end{array}$ & -49.38 & $\begin{array}{l}0.0176 \\
(0.07)\end{array}$ & 1.776 \\
\hline Central & $\begin{array}{l}0.352^{*} \\
(2.18)\end{array}$ & 42.17 & $\begin{array}{l}-0.870 * \\
(-2.46)\end{array}$ & -58.10 & $\begin{array}{l}0.00187 \\
(0.01)\end{array}$ & 0.187 \\
\hline Volta & $\begin{array}{l}-0.239 \\
(-1.38)\end{array}$ & -21.27 & $\begin{array}{l}0.0696 \\
(0.24)\end{array}$ & 7.213 & $\begin{array}{l}-0.0603 \\
(-0.20)\end{array}$ & -5.848 \\
\hline Eastern & $\begin{array}{l}0.493 * * * \\
(3.35)\end{array}$ & 63.72 & $\begin{array}{l}-0.373 \\
(-1.31)\end{array}$ & -31.11 & $\begin{array}{l}0.246 \\
(0.99)\end{array}$ & 27.84 \\
\hline Ashanti & $\begin{array}{l}0.424 \text { *** } \\
(3.53)\end{array}$ & 52.74 & $\begin{array}{l}-0.204 \\
(-0.97)\end{array}$ & -18.49 & $\begin{array}{l}0.984 \text { *** } \\
(5.46)\end{array}$ & 167.4 \\
\hline Brong Ahafo & 0.152 & 16.47 & $-1.389 * *$ & -75.06 & -0.538 & -41.61 \\
\hline
\end{tabular}




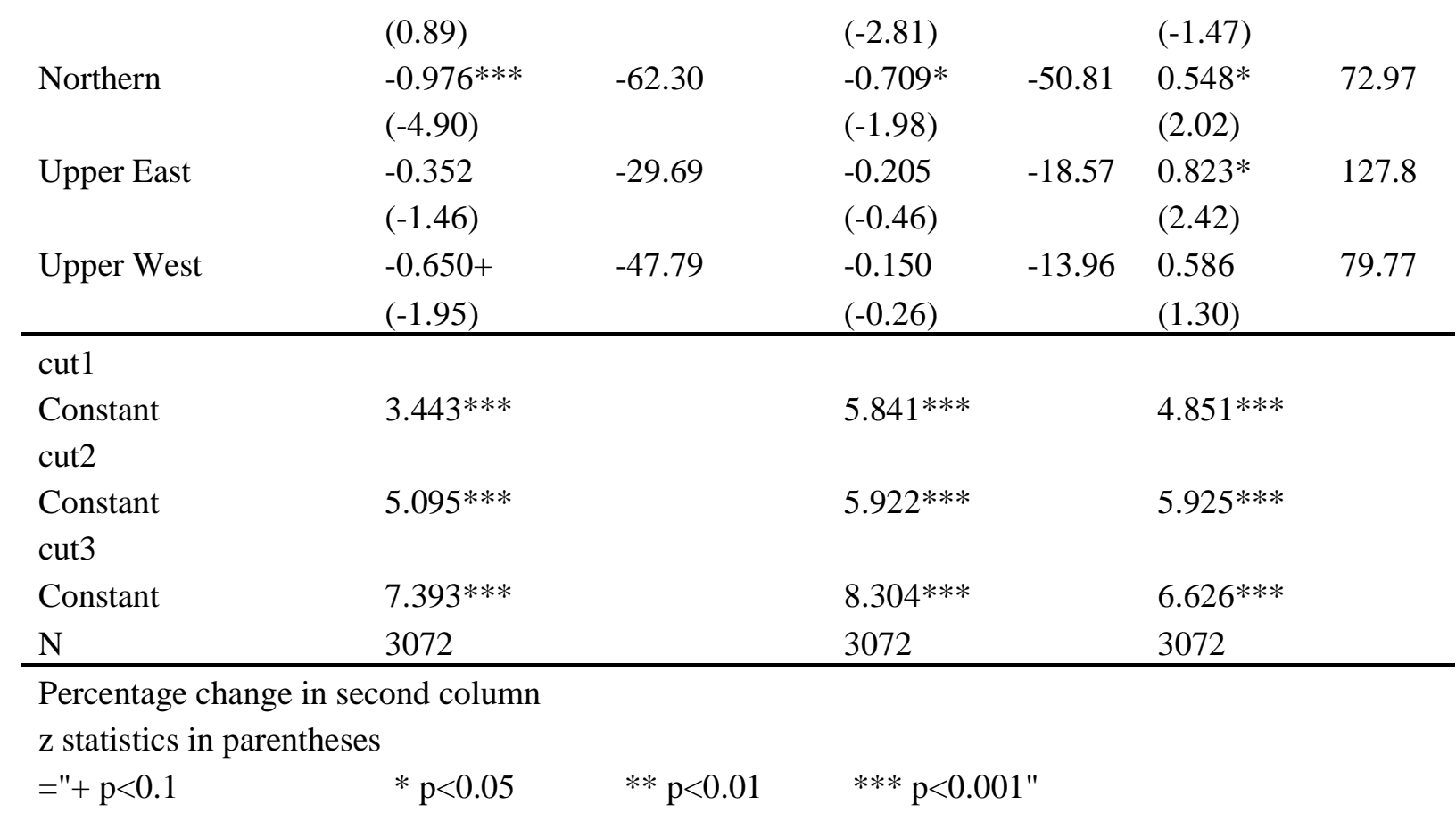

In terms of income, we observe that higher income levels compared with no income consistently show a positive and significant effect on the use of the various financial services across all models in the two countries. This finding corroborates the proposition that demand for financial services is an increasing function of income (Outreville, 1990). We also observe regional variation across countries and models. Compared to people in the Upper West region, inhabitants of the Central, Greater Accra, Eastern, Ashanti and Brong Ahafo regions are likely to use general account services. The situation is no different in South Africa, where the Western Cape is the reference province. The paper also included a set of dummy variables to control for the race of the respondent. Using blacks as the reference group, this paper show that the three other groups, i.e. Coloured, Asian and White, are more likely to use higher levels of these financial products. As discussed earlier, perceived and actual supply constraints tend to influence financial inclusion in developing countries. The models in Tables 1 and 2 show that as the number of perceived problems an individual has are reduced, the probability of using higher-level general accounts and services in Ghana and the use of insurance services in South Africa. However, this variable proves not be statistically significant in the other models. 
Table 2: Ordered Logit Estimation of Usage of Various Financial Services in South Africa

\begin{tabular}{|c|c|c|c|c|c|c|}
\hline & \multicolumn{2}{|c|}{$(\mathbf{1})$} & \multicolumn{2}{|c|}{$(2)$} & \multirow{2}{*}{\multicolumn{2}{|c|}{$\begin{array}{c}(3) \\
\text { Investment }\end{array}$}} \\
\hline & \multicolumn{2}{|c|}{ General Account and Services } & \multicolumn{2}{|c|}{ Insurance } & & \\
\hline & Coef & $\% \Delta$ & Coef & $\% \Delta$ & Coef & $\% \Delta$ \\
\hline Female & $\begin{array}{l}0.23^{*} \\
(2.15)\end{array}$ & 25.80 & $\begin{array}{l}0.43 * * * \\
(4.12)\end{array}$ & 54.36 & $\begin{array}{l}0.02 \\
(0.16)\end{array}$ & 1.72 \\
\hline Age & $\begin{array}{l}0.00 \\
(0.56)\end{array}$ & 0.237 & $\begin{array}{l}0.03 * * * \\
(7.91)\end{array}$ & 3.461 & $\begin{array}{l}0.00 \\
(0.41)\end{array}$ & 0.17 \\
\hline HH. Size & $\begin{array}{l}-0.01 \\
(-0.31)\end{array}$ & -0.737 & $\begin{array}{l}-0.02 \\
(-0.75)\end{array}$ & -1.914 & $\begin{array}{l}0.01 \\
(0.26)\end{array}$ & 0.56 \\
\hline Urban & $\begin{array}{l}0.405^{* *} \\
(3.10)\end{array}$ & 49.99 & $\begin{array}{l}-0.15 \\
(-1.18)\end{array}$ & -14.16 & $\begin{array}{l}-0.21+ \\
(-1.66)\end{array}$ & -18.79 \\
\hline No. of Reason & $\begin{array}{l}0.01 \\
(0.06)\end{array}$ & 0.726 & $\begin{array}{l}-0.195+ \\
(-1.81)\end{array}$ & -17.71 & $\begin{array}{l}-0.06 \\
(-0.59)\end{array}$ & -5.90 \\
\hline Married & $\begin{array}{l}0.66^{* * * *} \\
(5.94)\end{array}$ & 94.30 & $\begin{array}{l}0.64 * * * \\
(5.80)\end{array}$ & 89.70 & $\begin{array}{l}0.06 \\
(0.49)\end{array}$ & 5.70 \\
\hline \multicolumn{7}{|l|}{ Education } \\
\hline High sch. & $\begin{array}{l}0.85^{* * * *} \\
(4.98)\end{array}$ & 132.90 & $\begin{array}{l}0.51 * * \\
(3.11)\end{array}$ & 66.51 & $\begin{array}{l}0.05 \\
(0.31)\end{array}$ & 5.10 \\
\hline Technical sch. & $\begin{array}{l}2.13 * * * \\
(5.79)\end{array}$ & 741.70 & $\begin{array}{l}1.35^{* * *} \\
(3.30)\end{array}$ & 286.70 & $\begin{array}{l}-0.37 \\
(-0.96)\end{array}$ & -30.98 \\
\hline Matriculation/Univ. & $\begin{array}{l}1.55^{* * * *} \\
(8.76)\end{array}$ & 372.70 & $\begin{array}{l}1.11^{* * *} \\
(5.83)\end{array}$ & 202.10 & $\begin{array}{l}-0.15 \\
(-0.85)\end{array}$ & -14.01 \\
\hline \multicolumn{7}{|l|}{ Income } \\
\hline Below Average & $\begin{array}{l}0.63 * * \\
(3.20)\end{array}$ & 87.23 & $\begin{array}{l}0.40^{*} \\
(2.07)\end{array}$ & 49.44 & $\begin{array}{l}-0.23 \\
(-1.44)\end{array}$ & -20.79 \\
\hline Average Inc. & $\begin{array}{l}1.36^{* * *} \\
(6.64)\end{array}$ & 289.20 & $\begin{array}{l}0.77 * * * \\
(3.87)\end{array}$ & 116.0 & $\begin{array}{l}0.05 \\
(0.33)\end{array}$ & 5.540 \\
\hline Above Av. Inc. & $\begin{array}{l}1.79 * * * \\
(9.41)\end{array}$ & 501.40 & $\begin{array}{l}1.57 \text { *** } \\
(8.46)\end{array}$ & 381.60 & $\begin{array}{l}0.16 \\
(1.02)\end{array}$ & 17.41 \\
\hline High inc. & $\begin{array}{l}3.80 * * * \\
(14.89)\end{array}$ & 4352.40 & $\begin{array}{l}4.20^{* * *} \\
(17.65)\end{array}$ & 6566.20 & $\begin{array}{l}0.44 * \\
(2.18)\end{array}$ & 55.94 \\
\hline \multicolumn{7}{|l|}{ Province } \\
\hline Eastern Cape & $\begin{array}{l}-0.34+ \\
(-1.93)\end{array}$ & -28.89 & $\begin{array}{l}-0.34+ \\
(-1.72)\end{array}$ & -28.46 & $\begin{array}{l}-0.01 \\
(-0.04)\end{array}$ & -0.831 \\
\hline Northern Cape & $\begin{array}{l}-0.38+ \\
(-1.86)\end{array}$ & -31.67 & $\begin{array}{l}-0.34 \\
(-1.56)\end{array}$ & -28.51 & $\begin{array}{l}-1.50 * * * \\
(-6.00)\end{array}$ & -77.60 \\
\hline Free State & $\begin{array}{l}-0.36+ \\
(-1.89)\end{array}$ & -30.45 & $\begin{array}{l}-0.33 \\
(-1.47)\end{array}$ & -27.87 & $\begin{array}{l}0.39 * \\
(2.26)\end{array}$ & 48.19 \\
\hline KwaZulu-Natal & $\begin{array}{l}-0.18 \\
(-1.01)\end{array}$ & -16.55 & $\begin{array}{l}-0.44 * \\
(-2.28)\end{array}$ & -35.87 & $\begin{array}{l}0.16 \\
(0.86)\end{array}$ & 17.31 \\
\hline North West & $\begin{array}{l}0.03 \\
(0.12)\end{array}$ & 2.926 & $\begin{array}{l}-0.67 * * \\
(-2.62)\end{array}$ & -48.63 & $\begin{array}{l}-0.58^{*} \\
(-2.52)\end{array}$ & -43.89 \\
\hline Gauteng & -0.19 & -17.31 & -0.25 & -22.24 & 0.18 & 20.10 \\
\hline
\end{tabular}


$(-1.02)$

Mpumlanaga

0.14

(0.60)

Limpopo

$-0.28$

$(-1.34)$

cut1

Constant

$2.37 * * *$

$3.50 * * *$

Constant

cut3

Constant

$\mathbf{N}$

Percentage change in second column

$z$ statistics in parentheses

$+p<0.1$

$* p<0.05$

$* * p<0.01$

$* * * p<0.001$
(1.03)

$(-1.34)$

0.22

$(-3.10)$

$-0.87 * * * \quad-58.19 \quad-0.32$

$(-3.71)$

(-1.38)

$2.97 * * *$

$-0.42$

$5.06^{* * *}$

$2.54 * * *$

$6.92 * * *$

$4.00 * * *$

3123

3123

In line with the second objective of decomposing the coefficient of gender to identify the relative contributions by economic characteristics and behavioural differences, we employed the non-linear version of the Blinder-Oaxaca decomposition technique (Sinning et al., 2008). The results of the decomposition for the various models are presented in Appendices D1 to D9. The results show that more 70 per cent of the coefficient of female in the general account and insurance models is explained by unobserved characteristics across gender. This implies that variation across gender in terms of financial use is explained by behavioural and perception characteristics other than the observed socio-economic characteristics analysed in these models. In the case of investment services, about 47 per cent of the gender differences are explained by unobserved characteristics.

\section{Conclusions}

This paper has used FinScope data to examine gender differentials in access to and use of financial products in Ghana and South Africa. The rationale was to contribute to the debate on the mixed empirical results as to whether there is gender discrimination in the use of financial services, and fuelled the discourse by identifying the sources of gender differentials in financial use, if any. The paper also contributes to the existing literature by way of examining the presence of gender discrimination in the use of financial services based on levels and types of financial transaction rather than on perceptions of financial barriers and aggregation of access and use of financial services. In this regard, the specific hypotheses tested in this paper are: (1) there is no gender difference in access and use of financial services; (2) gender differences, if any, are not explained by unobservable characteristics, and 
(3) patterns of gender differentials, if any, vary between Ghana and South Africa for the three types of financial service. The ordered logit regression model and non-linear decomposition technique akin to the Blinder-Oaxaca decomposition are employed to test the three hypotheses. As part of the data management, financial products were grouped under three main types of account: (1) general account and services, (2) insurance services, and (3) investment services.

Our results suggest that on the whole there is gender discrimination in the use of financial services in both Ghana and South Africa. The descriptive analysis shows that for each of the three types of financial service, the proportion of males is higher for advanced products. The evidence of gender discrimination in both Ghana and South Africa is statistically supported in the case of general accounts and services, and insurance products. The main observation is that females in South Africa are more likely to use general financial and investment products than in Ghana. Based on a stepwise regression analysis, we observed that in South Africa, the income effect offsets the observation from the descriptive analysis that more males use financial services. This suggests that one of the strategies for Ghana to address female discrimination in the use of financial service is to bridge the gender income gap. In most cases our decomposition results show that differences in unobserved characteristics are the major contributors to the observed coefficients. In Africa, a concerted effort is been made to enhance the provision of financial services and make them available at an affordable cost. However, this effort will be meaningful only when we focus on the specific sections of the population, such as women, who have been excluded significantly in the past. The findings of the paper contribute to the knowledge of levels and types of financial transactions among women, information that is useful in developing relevant products and policies, by removing perceived barriers. 


\section{References}

Annim, S., Arun, T., \& Kostov, P. (2012). Effect of perceptions and behaviour on access to and use of financial service: Evidence from South Africa. IZA Discussion Paper series No 7042, Bonn.

Aterido R., Beck T. and Iacovone L. (2011) Gender and Finance in Sub-Saharan Africa: Are Women Disadvantaged? Policy Research Working Paper 5571, The World Bank, Washington D. C.

Barslund, M., \& Tarp, F. (2008). Formal and informal rural credit in four provinces of Vietnam. The Journal of Development Studies, 44(4), 485-503.

Bauer, M., Chytilová, J., \& Morduch, J. (2012). Behavioral foundations of microcredit: Experimental and survey evidence from rural India. The American Economic Review, 102(2), $1118-1139$.

Bawumia, M., Owusu-Danso, T., \& McIntyre, A. (2008). Ghana's reforms transform its financial sector. IMF Survey Magazine: Countries \& Region, 1-4.

Claessens, S. (2006). Access to financial services: A review of the issues and public policy objectives. The World Bank Research Observer, 21(2), 207-240.

Daymont, T. N., and P. J. Andrisani. 1984. Job preferences, college major, and thegender gap in earnings. Journal of Human Resources, 19, 408-428.

Demirgüç-Kunt, A., Klapper, L. F., \& Singer, D. (2013). Financial Inclusion and Legal Discrimination Against Women: Evidence from Developing Countries (SSRN Scholarly Paper No. ID 2254240). Rochester, NY: Social Science Research Network. Retrieved from http://papers.ssrn.com/abstract=2254240

Finmark Trust. (2011). FinScope South Africa Small Business Survey 2010. Midrand: Finmark Trust.

Kostov, P., Arun, T., \& Annim, S. (2011). Determinants of access to finance: an investigation into the Mzansi intervention. European Journal of Development Research, 24(3), 397-412.

Morduch, J. (1999). The microfinance promise. Journal of economic Literature, 37(4), 15691614.

Muravyev, Alexander \& Talavera, Oleksandr \& Schäfer, Dorothea, 2009. "Entrepreneurs' gender and financial constraints: Evidence from international data," Journal of Comparative Economics, Elsevier, vol. 37(2), pages 270-286, June. 
Napier, M., Melamed, C., Taylor, G., \& Jaeggi, T. (2013). Promoting women's financial inclusion: A toolkit - Publications - GOV.UK. Department for International Development. Retrieved from https://www.gov.uk/government/publications/promoting-womens-financialinclusion-a-toolkit

Narain, S. (2009). Gender and Access to Finance. Analytical Paper, World Bank. Retrieved from http://siteresources.worldbank.org/EXTGENDERSTATS/Resources/SushmaNarainAccesstoFinanceAnalyticalPaper.doc

Osei-Assibey, E. (2009). Financial Exclusion: What drives supply and demand for basic financial services in Ghana? Savings and Development, 33(3), 207-238.

Outreville, J. F. (1990). The Economic significance of insurance markets in developing countries. The Journal of Risk and Insurance, 57(3), 487-498. doi:10.2307/252844

Sinning, M., Hahn, M., \& Bauer, T. K. (2008). The Blinder-Oaxaca decomposition for nonlinear regression models. The Stata Journal, 8(4), 480-492.

Stiglitz, J. E., \& Weiss, A. (1981). Credit rationing in markets with imperfect information. The American Economic Review, 71(3), 393-410. 


\section{APPENDICES}

Appendix 1: Classification of Type and Levels of Use of Financial Services

\begin{tabular}{|c|c|c|c|c|}
\hline \multirow{2}{*}{$\begin{array}{c}\text { Types of Financial } \\
\text { Service }\end{array}$} & \multicolumn{4}{|c|}{ Levels } \\
\hline & Pre(None) & Basic & Intermediate & Advance \\
\hline $\begin{array}{l}\text { General Accounts } \\
\text { and Services }\end{array}$ & $\begin{array}{l}\text { Mzansi and } \\
\text { Loan of a } \\
\text { Friend }\end{array}$ & $\begin{array}{l}\text { ATM, Savings } \\
\text { Book, Post Office } \\
\text { Account, Savings } \\
\text { and Transaction } \\
\text { Account, } \\
\text { Employer or } \\
\text { Microcredit } \\
\text { Institution }\end{array}$ & $\begin{array}{l}\text { Debit Card, Current or } \\
\text { Cheque account, Credit } \\
\text { Card, Fixed Deposit, } \\
\text { Mortgage, Money for } \\
\text { house either from } \\
\text { Government or Employer } \\
\text { and Personal Loan }\end{array}$ & $\begin{array}{l}\text { Money Market, Vehicle } \\
\text { Finance or Overdraft }\end{array}$ \\
\hline Investment & & $\begin{array}{l}\text { Lending to others } \\
\text { and benefitting } \\
\text { from their profit } \\
\text { and being a } \\
\text { member of } \\
\text { Stokvel/savings } \\
\text { club or burial } \\
\text { society }\end{array}$ & $\begin{array}{l}\text { Investment in } \\
\text { property/house/flat that } \\
\text { you rent out, Unit trusts, } \\
\text { Investment in } \\
\text { cattle/livestock and } \\
\text { Collectables } \\
\text { (antiques/carpets/paintings } \\
\text { /art/coins/stamps) }\end{array}$ & $\begin{array}{l}\text { Timeshares, Holiday } \\
\text { home/investment in a } \\
\text { second home, } \\
\text { Investment in vacant } \\
\text { land, farm land, own } \\
\text { business, someone } \\
\text { else's business, shares } \\
\text { on the stock market and } \\
\text { off-shore investment }\end{array}$ \\
\hline Insurance & & $\begin{array}{l}\text { Funeral Policy } \\
\text { with a big } \\
\text { institution, } \\
\text { Provident or } \\
\text { Pension Fund and } \\
\text { Educational Policy }\end{array}$ & $\begin{array}{l}\text { Life Assurance Policy, } \\
\text { Retirement Annuity, } \\
\text { Endowment/Investment } \\
\text { Policy, Homeowner's } \\
\text { insurance, Medical Aid, } \\
\text { Insurance taken out to } \\
\text { maintain credit payments } \\
\text { and Car Insurance }\end{array}$ & $\begin{array}{l}\text { Hospital Plan and } \\
\text { Medical or Household } \\
\text { content Insurance }\end{array}$ \\
\hline
\end{tabular}

Appendix A2: Supply Side Constraints on the Use of Financial Services in Ghana

\begin{tabular}{ll}
\hline Supply Side Factors (Ghana) & Frequency \\
\hline Banks have inconvenient hours of operating time & 52 \\
It costs too much to get to the bank & 73 \\
Banks offer low interest on returns & 73 \\
Account charges and fees are too high & 59 \\
Bank staff are discourteous or rude & 36 \\
Transactions take too long & 44 \\
The banking environment is intimidating & 20 \\
The bank is far away & 190 \\
Bank queues & 64 \\
\hline
\end{tabular}


Appendix A3: Supply Side Constraints on the Use of Financial Services in South Africa

Supply Side Factors (South Africa)

The bank is too far from where I live

It is expensive to have a bank account

It is too much hassle and not worht the effort

it is too expensive to save

The interest is too high
25

Frequency

49

39

397

296 
Appendix B: Ordered Logit Estimation of Usage of Various Financial Services in South Africa - With Race
(1)
(2)
(3)

\begin{tabular}{|c|c|c|c|c|c|c|}
\hline & \multicolumn{2}{|c|}{ General Account and Services } & \multicolumn{2}{|c|}{ Insurance } & \multicolumn{2}{|c|}{ Investment } \\
\hline & Coef. & $\% \Delta$ & Coef. & $\% \Delta$ & Coef. & $\% \Delta$ \\
\hline Female & $\begin{array}{l}0.22^{*} \\
(2.08)\end{array}$ & 24.89 & $\begin{array}{l}0.42 * * * \\
(3.94)\end{array}$ & 52.10 & $\begin{array}{l}0.02 \\
(0.22)\end{array}$ & 2.36 \\
\hline Age & $\begin{array}{l}-0.00136 \\
(-0.31)\end{array}$ & -0.136 & $\begin{array}{l}0.03 * * * \\
(7.23)\end{array}$ & 3.236 & $\begin{array}{l}0.00 \\
(1.13)\end{array}$ & 0.488 \\
\hline HH. Size & $\begin{array}{l}-0.01 \\
(-0.25)\end{array}$ & -0.598 & $\begin{array}{l}-0.02 \\
(-0.69)\end{array}$ & -1.789 & $\begin{array}{l}0.00 \\
(0.26)\end{array}$ & 0.57 \\
\hline Urban & $\begin{array}{l}0.31 * \\
(2.31)\end{array}$ & 35.96 & $\begin{array}{l}-0.21 \\
(-1.61)\end{array}$ & -19.28 & $\begin{array}{l}-0.09 \\
(-0.68)\end{array}$ & -8.36 \\
\hline No. of Reason & $\begin{array}{l}-0.01 \\
(-0.12)\end{array}$ & -1.481 & $\begin{array}{l}-0.21+ \\
(-1.94)\end{array}$ & -18.88 & $\begin{array}{l}-0.04 \\
(-0.39)\end{array}$ & -4.022 \\
\hline Married & $\begin{array}{l}0.62 * * * \\
(5.45)\end{array}$ & 85.20 & $\begin{array}{l}0.61 * * * \\
(5.48)\end{array}$ & 84.3 & $\begin{array}{l}0.13 \\
(1.14)\end{array}$ & 14.2 \\
\hline Education & & & & & & \\
\hline High sch. & $\begin{array}{l}0.76 * * * \\
(4.44)\end{array}$ & 113.10 & $\begin{array}{l}0.45 * * \\
(2.71)\end{array}$ & 56.61 & $\begin{array}{l}0.12 \\
(0.75)\end{array}$ & 13.26 \\
\hline Technical sch. & $\begin{array}{l}1.99 * * * \\
(5.46)\end{array}$ & 629.00 & $\begin{array}{l}1.23 * * \\
(2.92)\end{array}$ & 241.80 & $\begin{array}{l}-0.23 \\
(-0.56)\end{array}$ & -20.20 \\
\hline Matriculation/Univ. & $\begin{array}{l}1.40 * * * \\
(7.89)\end{array}$ & 307.10 & $\begin{array}{l}0.99 * * * \\
(5.17)\end{array}$ & 170.30 & $\begin{array}{l}0.00 \\
(0.03)\end{array}$ & 0.474 \\
\hline Income & & & & & & \\
\hline Below average & $\begin{array}{l}0.62 * * \\
(3.13)\end{array}$ & 86.61 & $\begin{array}{l}0.40 * \\
(2.03)\end{array}$ & 48.89 & $\begin{array}{l}-0.22 \\
(-1.32)\end{array}$ & -19.57 \\
\hline Average inc & $\begin{array}{l}1.41 * * * \\
(6.85)\end{array}$ & 311.10 & $\begin{array}{l}0.79 * * * \\
(3.94)\end{array}$ & 120.90 & $\begin{array}{l}0.01 \\
(0.05)\end{array}$ & 0.90 \\
\hline above av. Inc & $\begin{array}{l}1.86^{* * * *} \\
(9.54)\end{array}$ & 544.00 & $\begin{array}{l}1.59 * * * \\
(8.41)\end{array}$ & 390.70 & $\begin{array}{l}0.13 \\
(0.81)\end{array}$ & 13.61 \\
\hline High inc. & $\begin{array}{l}3.74 * * * \\
(14.63)\end{array}$ & 4103.70 & $\begin{array}{l}4.17 * * * \\
(17.44)\end{array}$ & 6337.20 & $\begin{array}{l}0.58^{* * *} \\
(2.77)\end{array}$ & 78.75 \\
\hline Province & & & & & & \\
\hline Eastern cape & $\begin{array}{l}-0.14 \\
(-0.75)\end{array}$ & -12.79 & $\begin{array}{l}-0.31 \\
(-1.64)\end{array}$ & -26.91 & $\begin{array}{l}-0.28 \\
(-1.46)\end{array}$ & -24.49 \\
\hline Northern Cape & $\begin{array}{l}-0.37+ \\
(-1.80)\end{array}$ & -30.81 & $\begin{array}{l}-0.32 \\
(-1.46)\end{array}$ & -27.42 & $\begin{array}{l}-1.55^{* * * *} \\
(-6.21)\end{array}$ & -78.84 \\
\hline Free State & $\begin{array}{l}-0.18 \\
(-0.89)\end{array}$ & -16.36 & $\begin{array}{l}-0.31 \\
(-1.40)\end{array}$ & -26.88 & $\begin{array}{l}0.10 \\
(0.51)\end{array}$ & 10.03 \\
\hline KwaZulu-Natal & $\begin{array}{l}-0.07 \\
(-0.34)\end{array}$ & -6.466 & $\begin{array}{l}-0.50 * \\
(-2.44)\end{array}$ & -39.34 & $\begin{array}{l}0.01 \\
(0.03)\end{array}$ & 0.700 \\
\hline North West & $\begin{array}{l}0.18 \\
(0.71)\end{array}$ & 19.41 & $\begin{array}{l}-0.69 * * \\
(-2.71)\end{array}$ & -49.60 & $\begin{array}{l}-0.82 * * * \\
(-3.36)\end{array}$ & -56.01 \\
\hline
\end{tabular}




\begin{tabular}{|c|c|c|c|c|c|c|}
\hline Gauteng & $\begin{array}{l}0.01 \\
(0.03)\end{array}$ & 0.54 & $\begin{array}{l}-0.24 \\
(-1.31)\end{array}$ & -21.51 & $\begin{array}{l}-0.12 \\
(-0.63)\end{array}$ & -11.25 \\
\hline Mpumlanaga & $\begin{array}{l}0.38 \\
(1.58)\end{array}$ & 45.48 & $\begin{array}{l}-0.75 * * \\
(-2.96)\end{array}$ & -52.61 & $\begin{array}{l}-0.11 \\
(-0.52)\end{array}$ & -10.70 \\
\hline Limpopo & $\begin{array}{l}-0.08 \\
(-0.35)\end{array}$ & -7.51 & $\begin{array}{l}-0.86 * * * \\
(-3.66)\end{array}$ & -57.83 & $\begin{array}{l}-0.60^{*} \\
(-2.53)\end{array}$ & -45.32 \\
\hline \multicolumn{7}{|l|}{ Race } \\
\hline Coloured & $\begin{array}{l}0.25 \\
(1.51)\end{array}$ & 28.02 & $\begin{array}{l}-0.03 \\
(-0.17)\end{array}$ & -2.81 & $\begin{array}{l}-0.49^{* *} \\
(-2.95)\end{array}$ & -38.66 \\
\hline Asian & $\begin{array}{l}0.87 * * * \\
(3.44)\end{array}$ & 137.60 & $\begin{array}{l}0.67+ \\
(1.94)\end{array}$ & 94.65 & $\begin{array}{l}-1.30 * * * \\
(-4.67)\end{array}$ & -72.85 \\
\hline White & $\begin{array}{l}1.07 * * * \\
(5.65)\end{array}$ & 191.40 & $\begin{array}{l}0.60 * * \\
(3.13)\end{array}$ & 81.67 & $\begin{array}{l}-1.04 * * * \\
(-4.88)\end{array}$ & -64.68 \\
\hline \multicolumn{7}{|l|}{ cut1 } \\
\hline $\begin{array}{l}\text { Constant } \\
\text { cut2 }\end{array}$ & $2.36 * * *$ & & $2.82 * * *$ & & -0.50 & \\
\hline $\begin{array}{l}\text { Constant } \\
\text { cut3 }\end{array}$ & $3.49 * * *$ & & $4.91 * * *$ & & $2.51 * * *$ & \\
\hline Constant & $7.27 * * *$ & & $6.80 * * *$ & & $3.10 * * *$ & \\
\hline $\mathbf{N}$ & 3123 & & 3123 & & 3123 & \\
\hline \multicolumn{7}{|c|}{$\begin{array}{l}\text { Percentage change in second column } \\
z \text { statistics in parentheses }\end{array}$} \\
\hline$+p<0.1$ & $* p<0.05$ & $* * p<0.01$ & $* * * p<0$ & & & \\
\hline
\end{tabular}


Appendix C1 : Descriptive statistics for Ghana model

\begin{tabular}{lllll}
\hline Variable & Mean & Std. Dev. & Min & Max \\
\hline General account and services & 1.65 & 0.84 & 1 & 4 \\
Investment & 1.19 & 0.60 & 1 & 4 \\
Insurance & 1.16 & 0.57 & 1 & 4 \\
Gender (Female) & 0.55 & 0.50 & 0 & 1 \\
Age & 37.16 & 15.82 & 15 & 97 \\
Basic sch. & 0.53 & 0.50 & 0 & 1 \\
Secondary Sch. & 0.16 & 0.37 & 0 & 1 \\
Post sec sch. & 0.03 & 0.16 & 0 & 1 \\
University & 0.05 & 0.21 & 0 & 1 \\
HH size & 2.89 & 1.81 & 1 & 15 \\
Urban & 0.41 & 0.49 & 0 & 1 \\
Supply Side Constraints & 0.23 & 0.60 & 0 & 7 \\
Married & 0.55 & 0.50 & 0 & 1 \\
Below 600 & 0.82 & 0.39 & 0 & 1 \\
Betw. 601 and 1200 & 0.02 & 0.15 & 0 & 1 \\
Betw. 1201 and 1800 & 0.00 & 0.06 & 0 & 1 \\
Over 1801 & 0.00 & 0.05 & 0 & 1 \\
Western & 0.11 & 0.32 & 0 & 1 \\
Central & 0.07 & 0.26 & 0 & 1 \\
Volta & 0.08 & 0.27 & 0 & 1 \\
Eastern & 0.11 & 0.31 & 0 & 1 \\
Ashanti & 0.21 & 0.41 & 0 & 1 \\
Brong Ahafo & 0.08 & 0.26 & 0 & 1 \\
Northern & 0.10 & 0.30 & 0 & 1 \\
Upper East & 0.05 & 0.21 & 0 & 1 \\
Upper West & 0.03 & 0.16 & 0 & 1 \\
\hline
\end{tabular}


Appendix C2: Descriptive statistics for South Africa models

\begin{tabular}{lllll}
\hline Variable & Mean & Std. Dev. & Min & Max \\
\hline General account and services & 2.03 & 0.98 & 1 & 4 \\
Investment & 1.70 & 0.67 & 1 & 4 \\
Insurance & 1.78 & 0.97 & 1 & 4 \\
Gender (Female) & 0.54 & 0.50 & 0 & 1 \\
Age & 35.25 & 15.56 & 16 & 95 \\
HH. Size & 3.57 & 3.14 & 0 & 30 \\
Urban & 0.63 & 0.48 & 0 & 1 \\
Supply Side Constraints & 0.21 & 0.47 & 0 & 3 \\
Married & 0.35 & 0.48 & 0 & 1 \\
High sch. & 0.42 & 0.49 & 0 & 1 \\
Technical sch. & 0.02 & 0.14 & 0 & 1 \\
Matriculation/Univ. & 0.40 & 0.49 & 0 & 1 \\
Below average & 0.20 & 0.40 & 0 & 1 \\
Average & 0.14 & 0.35 & 0 & 1 \\
Above average & 0.28 & 0.45 & 0 & 1 \\
High income & 0.17 & 0.37 & 0 & 1 \\
Eastern cape & 0.14 & 0.35 & 0 & 1 \\
Northern Cape & 0.02 & 0.15 & 0 & 1 \\
Free State & 0.07 & 0.25 & 0 & 1 \\
KwaZulu-Natal & 0.21 & 0.41 & 0 & 1 \\
North West & 0.06 & 0.24 & 0 & 1 \\
Gauteng & 0.21 & 0.41 & 0 & 1 \\
Mpumlanaga & 0.09 & 0.28 & 0 & 1 \\
Limpopo & 0.11 & 0.31 & 0 & 1 \\
Coloured & 0.09 & 0.28 & 0 & 1 \\
Asian & 0.03 & 0.17 & 0 & 1 \\
White & 0.09 & 0.28 & 0 & 1 \\
\hline & & & & 1 \\
\hline
\end{tabular}


Appendix D1: Decomposition of general account and services - South Africa

\begin{tabular}{lllll}
\hline & Coef & Percentage & Std. Err & Z \\
\hline Explained & -0.11 & 3451.13 & 0.03 & -3.96 \\
Unexplained & 0.11 & -3351.13 & 0.06 & 1.75 \\
Total & 0.00 & 100.00 & 0.07 & -0.05 \\
\hline
\end{tabular}

Note: Bootstrap standard errors; 100 repetitions

Appendix D2: Decomposition of insurance model - South Africa

\begin{tabular}{lllll}
\hline & Coef & Percentage & Std. Err & Z \\
\hline Explained & -0.11 & 1086.52 & 0.02 & -5.00 \\
Unexplained & 0.10 & -986.52 & 0.06 & 1.68 \\
Total & -0.01 & 100.00 & 0.07 & -0.15 \\
\hline
\end{tabular}

Note: Bootstrap standard errors; 100 repetitions

Appendix D3: Decomposition of investment model - South Africa

\begin{tabular}{lllll}
\hline & Coef & Percentage & Std. Err & Z \\
\hline Explained & -0.01 & 10.91 & 0.02 & -0.63 \\
Unexplained & -0.12 & 89.09 & 0.15 & -0.78 \\
Total & -0.13 & 1.00 & 0.15 & -0.9 .00 \\
\hline
\end{tabular}

Note: Bootstrap standard errors; 100 repetitions

Appendix D4: Decomposition extended general account and services model-South Africa

\begin{tabular}{lllll}
\hline & Coef & Percentage & Std. Err & Z \\
\hline Explained & -0.12 & 406.08 & 0.02 & -4.85 \\
Unexplained & 0.09 & -306.08 & 0.06 & 1.42 \\
Total & -0.03 & 100.00 & 0.07 & -0.42 \\
\hline
\end{tabular}

Note: Bootstrap standard errors; 100 repetitions 
Appendix D5: decomposition extended insurance model-South Africa

\begin{tabular}{lllll}
\hline & Coef & Percentage & Std. Err & Z \\
\hline Explained & -0.12 & 1322.90 & 0.03 & -4.35 \\
Unexplained & 0.11 & -1222.90 & 0.06 & 1.70 \\
Total & -0.01 & 100.00 & -0.12 & 0.91 \\
\hline
\end{tabular}

Note: Bootstrap standard errors; 100 repetitions

Appendix D6: Decomposition of extended investment model-South Africa

\begin{tabular}{lllll}
\hline & Coef & Percentage & Std. Err & Z \\
\hline Explained & 0.00 & 8.33 & 0.02 & -0.18 \\
Unexplained & -0.05 & 91.67 & 0.14 & -0.32 \\
Total & -0.05 & 100.00 & 0.14 & -0.35 \\
\hline
\end{tabular}

Note: Bootstrap standard errors; 100 repetitions

Appendix D7: Decomposition of general account and services model-Ghana

\begin{tabular}{lllll}
\hline & Coef & Percentage & Std. Err & Z \\
\hline Explained & -0.06 & 32.36 & 0.02 & -3.14 \\
Unexplained & -0.12 & 67.64 & 0.04 & -2.87 \\
Total & -0.18 & 100.00 & 0.04 & -4.65 \\
\hline
\end{tabular}

Note: Bootstrap standard errors; 100 repetitions

Appendix D8: Decomposition of insurance model-Ghana

\begin{tabular}{lllll}
\hline & Coef & Percentage & Std. Err & Z \\
\hline Explained & -0.12 & 23.25 & 0.03 & -4.35 \\
Unexplained & 0.11 & 76.75 & 0.06 & 1.70 \\
Total & -0.24 & 100.00 & 0.09 & -2.67 \\
\hline
\end{tabular}

Note: Bootstrap standard errors; 100 repetitions

Appendix D9: Decomposition of investment model-Ghana

\begin{tabular}{lllll}
\hline & Coef & Percentage & Std. Err & Z \\
\hline Explained & -0.06 & 53.42 & 0.02 & -2.43 \\
Unexplained & -0.19 & 46.58 & 0.09 & -2.09 \\
Total & -0.24 & 100.00 & 0.09 & -2.67 \\
\hline
\end{tabular}

Note: Bootstrap standard errors; 100 repetitions 